\title{
THE EFFECT OF USING PROJECT-BASED INQUIRY LEARNING (PIL) STEM MODULE IN TOPIC SPACE AMONG YEAR ONE STUDENTS
}

\author{
Chee Hoe Ng ${ }^{1}$, Mazlini Adnan ${ }^{2}$ \\ 1 SJK(C) Kai Chee, Pulau Pinang, Malaysia. \\ 2 Assoc. Prof. Dr., Department of Mathematics, Faculty of Science and Mathematics, Universiti Pendidikan Sultan Idris. \\ ngcheehoe79@gmail.com, mazlini@fsmt.upsi.edu.my
}

\begin{abstract}
The purpose of this study is to examine the effect of integration STEM education by using STEM module designed based on four phases in the Project-based Inquiry Learning (PIL) method. The STEM module consists of five projects in the topic Space in the Year One DSKP of the review KSSR Mathematics in Malaysia. The effectiveness of using the STEM module is assessed on the understanding, interest and attitude towards STEM education. The study was conducted on 33 students in the experimental group and 26 students in the control group. The instruments used in this research are STEM module, pre-test and post-test and questionnaire on students' understanding on STEM, interest in STEM and attitude towards STEM education. The STEM module covered the various cultured races in Malaysia and consist five projects. The concept and description of STEM content in each project has been emphasized in the module. The findings show that the STEM module has a satisfactory validity with a percentage of agreement is $95 \%$ and a satisfactory reliability with a Cronbach's alpha value of 0.701 . Mathematics achievement score analysis for the experimental group showed a high significance $(\mathrm{p}<0.01)$ in the post-test compared to the pre-test. The findings also showed that there is an increasing in understanding, interest and attitude in the experimental group. In conclusion, the STEM module designed based on the PIL method had satisfactory validity and reliability and can be a reference for teachers to carry out STEM in primary Mathematics.
\end{abstract}

Keywords:

STEM education, Project-based Inquiry Learning (PIL), STEM module, KSSR, 21st learning skills, Space Article Received: 18 October 2020, Revised: 3 November 2020, Accepted: 24 December 2020

\section{Introduction}

STEM education is the integration of teaching and learning in science, technology, engineering and mathematics. In order to develop national economy, STEM education has played an important role and can contribute human resources to the development of the country. The progress of STEM education in Malaysia's education system is significant mentioned in the Malaysia Education Blue Print (PPPM) 20132025. The aim of PPPM 2013-2025 is to make a change of the education system in Malaysia so that able to confront with the growth of international education system. To achieve this goal, Malaysia Ministry of Education (MOE) has identified 11 shifts that need to be implemented in order to produce changes in the education system in Malaysia. The first shift in the PPPM 20132025 is to provide an equal access to quality education of an international standard. One of the benchmark outputs in the PPPM 2013-2025 is to strengthen the quality of Science, Technology, Engineering, and Mathematics (STEM) education.

STEM education should be applied in the curriculum in order to produce students who are creative, crisis and innovative (KPM, 2013). Integration STEM subjects able to dig out the talents and cultivate students' interest in the Science and Mathematics in order to achieve the aspirations expected in PPPM 2013-2025. According Curriculum Development Division (BPK, 2016), the goal of STEM education is to make STEM as a culture in students' life and this method is not only applied in learning and teaching, but the experience gained can be used to solve issues or problems in the daily life.

Besides that, to produce the students fulfilled the needs of 21st century skills, STEM 
education has the qualifications. According to Hays Blaine (2009), STEM education offers students one of the best opportunities to make sense of the world holistically, rather than in bits and pieces. In view of Hays Blaine (2009), STEM education had removed the traditional barriers erected between the four disciplines and integrating these four disciplines into a one cohesive teaching and learning paradigm. Whereas according Tsupros, Kohler and Hallinen (2009) and Becker \& Park (2011), STEM education is an approach to the integration of four disciplines in the field of STEM. The concept of STEM education is related to real-world lessons so that students can apply science, technology, engineering and mathematics in a daily context that allows students to make connections with schools, society, workplace and in global efforts to develop STEM education. From the views of Hays Blaine (2009), Tsupros, Kohler and Hallinen (2009), Becker \& Park (2011), we can conclude that STEM education is not an obstacle for educators or students, instead STEM education is a direction that needs to be developed for today's education world so that students can make the connection of STEM knowledge in daily life.

In PPPM 2013 - 2025, MOE mentioned five factors or problems that cause a decrease in the number and quality of students in the field of STEM education, that is:

i. Limited awareness about STEM education.

ii. Considered difficulty of STEM subjects.

iii. A heavy-content curriculum.

iv. Inconsistent quality of the teaching and learning method.

v. Out-dated and insufficient infrastructure.

To achieve MOE's aspirations in PPPM 2013 - 2025, these problems need to be overcome. In 2014, in the Global Science and Innovation Advisory Council (GSIAC) Conference at New
Work, Second Minister of Education Malaysia had come out with the STEM Educational Conceptual Framework. In this framework, the progress of the STEM education in Malaysia was divided into six phases. From the early childhood phase to industry or community phase. In this study, the focused is on the primary school students and the objective is helping them to connect or build up the foundation on STEM education.

For the primary school, the main goal of STEM education is to give awareness to the importance of STEM education and to give an initial concept about integration STEM education to the students.

To introduce STEM education to primary schools, the first step is to provide a learning standard on inquiry-based learning method and problem solving in real situations in daily life. In other words, STEM education needs to be planned carefully using the inquiry learning method so that it can provide opportunities for students to think scientifically to solve problems in real life situations through training.

The purpose of this study is to design a STEM module based on the Project-Based Inquiry Learning (PIL) method to help educators to enhance the student's understanding on STEM, interest in STEM and attitude towards STEM education as well as mathematics achievement for Year One students in the topic of Space.

\section{Literature Review}

The PIL method is one of the STEM education teaching approaches that combines discovery inquiry teaching method and project-based learning method. According to Aminah et al. (2015), PIL method has been adapted according to the phases in the inquiry learning cycle. The PIL method was chosen because it focused on the scientific skills and attitudes, higher order thinking skills, creative problem solving, project 
construction and able to encourage students to communicate and work in groups.

This PIL method had four phases:

\section{Phase 1: Inquiry}

Teacher stimulates students by asking them questions to get them thinking while solving the problems. Teacher guides the students to build up a big idea on how to solve the problems and the student will decide the investigated issue.

\section{Phase 2: Exploration}

In the exploration phase, students explore various resources with the teacher to obtain information about the project to been produce. Students also need to find a variety information while planning the process to solve problems. After getting all the necessary information, students begin to draft, to create and to prepare materials for the project.

\section{Phase 3: Design and Experimentation}

In this phase, students start to develop their projects which they had planned in the exploration phase. Students will expose and test the projects is working or not, to solve the problems encountered and they will answer the questions had been asked in the inquiry phase. Students manipulate technological materials and tools to produce projects.

\section{Phase 4: Reflection}

In the last phase in PIL method, students present their projects. Students will review on the learning process. They will give some views on the project or product that they have made. In this phase, parents can be invited to validate the students' work and at the same time can encourage them to share their experiences with parents.

This PIL method are adapted and modified from the STEM education in the PERMATA curriculum - elementary education in Malaysia. The purposed of the adaption and modification is hoping that the PIL method able to applied into Malaysia primary school's curriculum.

The PIL method is a STEM pedagogy method that should be used in teaching and learning STEM education as shown in Figure 1. Inquiry is the initial to stimulates students' curiosity and lead the students to find the answers. $3 \mathrm{E}$ in PIL method is Explore, Experiment and Experience. 3C in PIL method is Collaboration, Creativity and Communication. The $3 \mathrm{C}$ in PIL method is three elements in the 21 st learning skills. Integration of these four subjects not only to study in theory but the skills contained in the STEM education are related to the 21 st century skills. According to Gitta \& Patrick (2016), STEM skills belong to the group of technical skills. These skills included the ability to produce scientific knowledge which supported by mathematical knowledge and skills to invent and construct a technological and scientific product. In other words, STEM skills and knowledge cannot be measured by current discipline classifications. The integration of STEM education through PIL methods affects pedagogical knowledge, skills and attitudes (Ong et al. 2016).

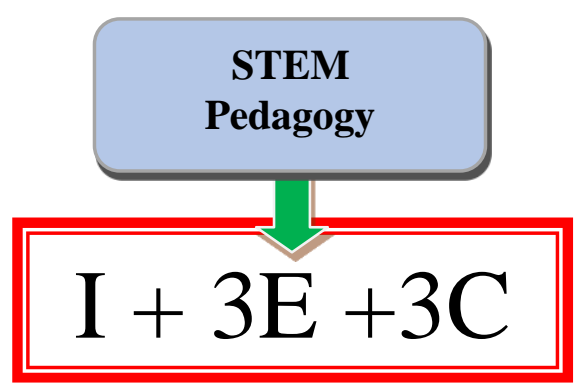

STEM Module

Figure 1. Project Inquiry-Based Learning (PIL) Method 
STEM module used in this research are develop using the four phases of PIL method which recommended by Aminah et al. (2015) and in this STEM module some modification had been done to these four phases so that it will suit to Year One students.

Researchers choose the PIL method to develop the STEM module because PIL method emphasizes on scientific skills and attitudes, higher order thinking skills, creative problem solving, development of objects based on design and technology that will motivate the students to communicate and work in teams.

The advantages of using the PIL method in the development of this STEM module because the PIL method already contains $3 \mathrm{E}$ and $3 \mathrm{C}$ implicitly in it. To implement STEM-based teaching and learning, $3 \mathrm{E}$ and $3 \mathrm{C}$ have played their roles. $3 \mathrm{E}$ is an element that should be practiced in the teaching and learning STEM pedagogy. In the exploring, the $3 \mathrm{E}$ able to encourage the curiosity of students and to make the students to keep thinking on how to get the answers or explanations. In experimentation phase, students conduct the experiments to prove their answers. After proving them, students use their experience to explain the answers.

$3 \mathrm{C}$ is the three skills that contained in $21 \mathrm{st}$ century skills. Cooperation is an important element in the PIL method. As students work together to produce a project, they will use creativity during project production. Students also communicate to get the best solution to produce a project.

The PIL method which contains the elements of inquiry, $3 \mathrm{E}$ and $3 \mathrm{C}$ are the teaching and learning methods that need to be applied in the implementation of STEM education. In the opinion of researcher, the teaching of STEM education is not only an imparting knowledge, but more to inspire students to discover various aspects in our lives.

Table 1. STEM Module's Content

\begin{tabular}{|c|c|c|}
\hline No & Project & STEM's Concept or the Idea Involved \\
\hline 1 & Tanglung & $\begin{array}{l}\text { Various size and shape of two-dimensional shapes, quantity of } \\
\text { materials that needed, such as color paper, candle, design and } \\
\text { the usage of the Tanglung. }\end{array}$ \\
\hline 2 & Tudung Saji & $\begin{array}{l}\text { Measurement or size, the quantity of stripes needed, shape, } \\
\text { design and the usage of the Tudung Saji. }\end{array}$ \\
\hline 3 & Kolam & $\begin{array}{l}\text { Different color rice or sands and the different symmetry pattern } \\
\text { or design of two-dimensional shapes on Kolam. }\end{array}$ \\
\hline 4 & Wau & $\begin{array}{l}\text { Measurement or size of the Wau, symmetry and the scientific } \\
\text { concept that make the Wau fly in the sky. }\end{array}$ \\
\hline 5 & Chinese Yoyo & $\begin{array}{l}\text { Measurement, size, symmetry and the concept on how to } \\
\text { balancing the Chinese Yoyo. }\end{array}$ \\
\hline
\end{tabular}

\section{Methodology}

The aim of this study is to examine the effectiveness of using the STEM module based on four phases in the PIL method. The purpose of using this module is to examine the understanding, interest and attitude towards STEM education and mathematics achievement among Year One students in the topic of Space. The finding data on the understanding on STEM education, interest in STEM education and attitude towards STEM education and achievement of Mathematics are conducted through quantitative researches. 
In this research, the study sample is the Year One primary school students and the sample consists of 59 Year One students of primary school in North Seberang Perai district, Penang. 33 students are arranged into an experimental group and 26 students are arranged into the control group.

In this research, pre-post tests were used as an instrument to assess students' Mathematical achievement in the topic of Space. According to Chua (2014), pre-post-test design involves two measurements (same measurement) on the dependent variable, i.e., before and after the variable is manipulated. The purpose is to find out the effect of the independent variable causing a change to the dependent variable.

\section{Pre-test and Post-test}

According to Muskamal (1991), academic achievement refers to the scores or grades achieved by students in a test or examination. In this research, Mathematics achievement refers to the ability of students to answer pre-test and posttest questions related to the learning standard 7.1.1, Name the shape of cuboid, cube, cone, squarebased pyramid, cylinder and sphere and learning standard 7.1.2, Describe face, edge and vertex of three-dimensional shapes in DSKP Mathematics Year One Review KSSR (BPK, 2015). Pre-test questions were given to both research groups before the PIL method and the traditional method were conducted. While post-test questions were given to both groups after the PIL method and the traditional method were implied to both groups.

\section{Questionnaire on Understanding on STEM, Interest in STEM and Attitude Towards STEM Education}

A questionnaire about the understanding on STEM, interest in STEM and attitude towards STEM education was prepared by the researcher. This questionnaire was conducted after all the projects in the module were produced. The items in this survey consisted of three constructs and 30 items. The three constructs to be studied are as follows: (a) students' understanding on STEM education, (b) students' interest in STEM education and (c) students' attitude towards STEM education.

A pilot study was conducted to identify the suitability of the questionnaire items before the actual study was conducted. A pilot study was conducted on another group of Year One students before the study start. The purpose of this pilot study is to determine the reliability of the research questionnaire instrument used and to prove the internal validity of the research instrument. The reliability of the questionnaire items was tested by finding the value of Cronbach's alpha $(\alpha)$

Table 2. Reliability Statistics on the Understanding, Interest and Attitude towards STEM Education

\begin{tabular}{cc}
\hline Questionnaire & Reliability Index \\
\hline Understanding & 0.766 \\
Interest & 0.737 \\
Attitude & 0.860 \\
\hline
\end{tabular}

Cronbach's alpha $(\alpha)$ value reliability analysis was used to determine the instrument's internal consistency index. For students' understanding on STEM education, the $(\alpha)$ value obtained is 0.766 . The $(\alpha)$ value on students' interest in STEM education is 0.737 , while for students' attitude towards STEM education is 0.860 . Table 2 shown the reliability statistics on the survey items in this study. 
Research Progress

This duration carries out the projects in the STEM module using PIL method as shown in Table 3.

The progress takes about six weeks

Table 3. Duration Carries Out the STEM Project

\begin{tabular}{clc}
\hline No & \multicolumn{1}{c}{ Activity } & Duration \\
\hline 1 & Introduction STEM Education & 1 week \\
2 & Project 1 - Tanglung & 1 week \\
3 & Project 2 - Tudung Saji & 1 week \\
4 & Project 3 - Kolam & 1 week \\
5 & Project 4 - Wau & 1 week \\
6 & Project 5 - Chinese Yoyo & 1 week \\
\hline
\end{tabular}

\section{Results and Discussion}

In this research, the PIL method using the STEM module is an independent variable. While the understanding, interest, attitude of students towards STEM education and achievement of
Mathematics in the topic of Space are the dependent variables. Quantitative data findings were analysed based on the findings of pre-test, post-test and questionnaire.

\section{Understanding on STEM, Interest in STEM and Attitude of Students Towards STEM Education}

Table 4. Mean and Standard Deviation on STEM education

\begin{tabular}{lcc}
\hline & Mean & Standard Deviation \\
\hline Understanding on STEM Education & 4.07 & 0.684 \\
\hline Interest in STEM education & 3.97 & 0.991 \\
\hline Attitudes Towards STEM Education & 3.97 & 1.05 \\
\hline
\end{tabular}

Table 4 shows the mean and standard deviation on STEM education. The mean score for students' understanding on STEM education is 4.07 and the standard deviation is 0.684 . The mean score for students' interests in STEM education is 3.97 and the standard deviation is 0.991 and the mean score for students' attitudes towards STEM education is 3.97 and the standard deviation is 1.05.

From these findings, we can make a conclusion. After the implementation of the STEM module with the PIL method, students had increased their understanding and interested on STEM education and they also changed their attitude towards the STEM education. Besides the findings from the questionnaire, the researcher also found out that while the students were working on the project in their group, they were able to collaborate with their group members to solve the problem during the process of the project through observation. They also become more active and willing to answer the questions from their teacher.

\section{Pre-Test and Post-Test Analyse}

Table 5. Mean and Standard Deviation on Pre-Test and Post-Test

\begin{tabular}{ccccc}
\hline & \multicolumn{2}{c}{ Pre-test } & \multicolumn{2}{c}{ Post-test } \\
Learning Standard & Experimental & Control & Experimental & Control \\
& Group & Group & Group & Group \\
\hline 7.1 .1 & & & \\
\hline
\end{tabular}




\begin{tabular}{ccccc}
\hline Mean & 3.88 & 2.23 & 5.94 & 5.31 \\
Standard Deviation & 1.474 & 1.728 & 0.242 & 0.549 \\
7.1 .2 & & & & \\
Mean & 9.61 & 7.19 & 10.48 & 9.12 \\
Standard Deviation & 0.966 & 2.757 & 0.712 & 1.071 \\
\hline
\end{tabular}

Table 5 shows the mean and standard deviations of pre-test and post-test standards for both the experimental group and the control group. These findings show that the mean pre-test for learning standard 7.1.1 for the experimental group $(\mathrm{M}=$ $3.88, \mathrm{SD}=1.474)$ is lower than the post-test $(\mathrm{M}=$ $5.94, \mathrm{SD}=0.242$ ). The mean of the pre-test for learning standard 7.1.2 for the experimental group
$(\mathrm{M}=9.61, \mathrm{SD}=0.966)$ was lower than the posttest $(\mathrm{M}=10.48, \mathrm{SD}=0.712)$. The mean of the pre-test for learning standard 7.1.1 for the control group $(\mathrm{M}=2.23, \mathrm{SD}=1.728)$ was lower than the post-test $(\mathrm{M}=5.31, \mathrm{SD}=0.549)$. The mean pretest for learning standard 7.1.2 for the control group $(\mathrm{M}=7.19, \mathrm{SD}=2.757)$ was lower than the post-test $(\mathrm{M}=9.12, \mathrm{SD}=1.071)$.

Table 6 shows the Statistics Test Based on the Wilcoxon T Test for the experimental group

Table 6. Statistics Test Based on the Wilcoxon T Test for the Experimental Group

\begin{tabular}{ccc}
\hline & $\begin{array}{c}\text { Pre-test and Post Standard } \\
\text { for Learning Standard }\end{array}$ & $\begin{array}{c}\text { Pre-test and Post Standard } \\
\text { for Learning Standard }\end{array}$ \\
& 7.1 .1 & 7.1 .2 \\
\hline Z & $-4.658^{\mathrm{a}}$ & $-4.060^{\mathrm{a}}$ \\
Asymp. Sig. (2-tailed) & 0.000 & 0.000 \\
\hline
\end{tabular}

These findings have shown that Mathematical achievement for both experimental group and control group had improved. This analyse shown that traditional learning method also can improve students' Mathematical skills. This is because control group are also exposed to the same learning standard as experimental group. However, if compared to the mean score obtained for the students from the experimental group $(\mathrm{M}=5.94)$ for learning standard 7.1.1 and the mean score (M $=10.48$ ) for learning standard 7.1.2, both mean scores are higher than the control group $(\mathrm{M}=5.31)$ for learning standard 7.1.1 and $(\mathrm{M}=9.12)$ for learning standard 7.1.2. From these finding, we can make a conclusion, that the students from experimental group able to improve the Mathematics achievement through the STEM education.

\section{Conclusion}

The aim of this study is to develop a STEM module based on the PIL method as a resource to enhance the integration of STEM education in primary Mathematics. A teaching and learning method that implied on STEM knowledge, STEM skills, and values is to solve the real-life problems. The PIL method encourages students to have an inquiry to ask and to explore the environment through investigation and solve the real-world situations problem which able foster STEM practice. By using STEM module based on PIL method, teachers will be more confident to conduct STEM education in schools.

The findings from this research shown that after the use of STEM module based on the PIL method, it had increased students' understanding on STEM, interest in STEM and attitude towards STEM education. The findings of this study also have implications for students. The PIL method 
had built a learning working team among students to study, to complete assignments, test theories, make a planning and implement processes and solutions. Students had maximized their learning with sharing the prior knowledge, using their skills to help each other's and to discover the new information. To achieve the goals of PPPM 20132025, teachers had an important role and must change their minds to accept the challenges of this new era. By doing such, the teachers able to produce students which meet the needs of the 21 st century.

\section{Acknowledgements}

I would like to express my very great appreciation to Dr Mazlini Adnan. Her valuable suggestions during the planning and development of this research work had made this research smoothly. Her willingness to give her time so generously has been very much appreciated. I would also like to express my deepest gratitude to the principal of the primary school in North Seberang Perai district, Penang for enabling me to carry out the research in the school.

\section{REFERENCES}

[1] Aminah Ayob, Ong, E.T., Md Nasir Ibrahim, Mazlini Adnan., Jameyah Shariff, Noriah Ishak: STEM In the Early Childhood Education in Malaysia. Paper Presented at The Early Childhood Care \& Education International Rendezvous (Ecceir 2015), The Gardens Hotel, Kuala Lumpur, 4-6 August, 2015.

[2] Becker, K. \& Park, K.: "Effects of Integrative Approaches Among Science, Technology, Engineering, and Mathematics (STEM) Subjects on Students' Learning: A preliminary meta-analysis." Journal of STEM Education, Volume 12, 2011

[3] Chua, Y. P.: Research Methods and Statistics Book 2: Statistics Basic (2nd ed.), McGrawHill Education, Shah Alam, Malaysia, 2011.

[4] Gitta, S. \& Patrick, K.: Defining 'STEM' skills: review and synthesis of the literature,
Support document 1. NCVER, Commonwealth of Australia, 2016.

[5] Hays Blaine Lantz: Science, Technology, Engineering, and Mathematics (STEM) Education, What Form? What Function? 2009.

[6] Kementerian Pendidikan Malaysia: Dokumen Standard Sekolah Rendah, Semakan Kurikulum Standard Sekolah Rendah, Matematik Tahun Satu, Bahagian Pembangunan Kurikulum, Putrajaya, 2015.

[7] Kementerian Pendidikan Malaysia: Laporan Inisiatif Pengukuhan STEM, Pelan Pembangunan Pendidikan Malaysia, Gelombang 1 (2013-2015), Bahagian Perancangan dan Penyelidikan Dasar Pendidikan, Putrajaya, 2015.

[8] Kementerian Pendidikan Malaysia: Panduan Pelaksanaan Pengajaran dan Pembelajaran Berasaskan Inkuiri, Bahagian Pembangunan Kurikulum, Putrajaya, 2016.

[9] Ministry of Education: Malaysia Education Blueprint 2013 - 2025 (Preschool to PostSecondary Education), Kementerian Pendidikan Malaysia, 2013.

[10] Muskamal Mohemad Jonan: Persepsi dan Minat Pelajar-Pelajar Melayu Terhadap Matematik Mengikut Jantina dan Pencapaian. Projek Penyelidikan, Bangi: UKM, 1991.

[11] Ng, C.H. \& Mazlini Adnan, Integrating STEM Education Through Project-Based Inquiry Learning (PIL) iIn Topic Space Among Year One Pupils, IOP Conference Series Materials Science and Engineering 296(1):012020, 2018.

[12] Ong, E.T. Aminah Ayob, Md Nasir Ibrahim, Mazlini Adnan, Jameyah Shariff, Noriah Ishak: The Effectiveness of an In-Service Training of Early Childhood Teachers on STEM Integration through Project-Based Inquiry Learning (PIL). Journal of Turkish Science Education, July 2016, 13(Special Issue), 44-58.

[13] Tsupros, N., Kohler, R. \& Hallinen, J.: STEM Education: A Project to Identify the Missing 
Components, Intermediate Unit 1 and Carnegie Mellon, Pennsylvania, 2009. 